\title{
Evaluation of the Effect of Grazing Lands Top Dressing with Inorganic Fertilizer on Biomass Yields for Sustainable Animal Feed Production, Ethiopia: The Case of Participatory Approach
}

\author{
*Mekonnen Diribsa Abuye Tulu Warku Temesgen Waqgari Keba \\ Oromia Agricultural Research Institute, Bako Agricultural Research Center, P. O. Box 03, Bako, Ethiopia
}

\begin{abstract}
Sub-Saharan livestock production and productivity are very low due to poor quality and inadequate quantity of available feed. Henceforth, livestock production can be improved through good management of natural grasslands and introduction of improved fodder species with the supply of fertilizer and water to maintain high productivity. Pre-extension demonstration of grazing land improvement technologies were conducted in 2017/18 in six Agricultural growth program (AGP II) districts, namely, Boneya Boshe, Wayu Tuka, Guto Gida and Diga from East Wollega and Horro and Guduru districts from Horro Guduru Wallega zone to evaluate, select and popularize farmers' preferred technologies based on their selection criteria and to create awareness on the importance of the approved technologies. One representative potential peasant association (PA) was selected purposively from each district based on grazing land and livestock population potential and accessibility for field monitoring and visit. Farmers' selection was done based on interests of farmers in trial management, willingness and ownership of sufficient grazing land to accommodate the trials and gender equality. In each PA, one farmer's extension research group (FREG) comprising 16 farmers were established to evaluate and select the technologies. Training was given to farmers, DAs and experts. Three treatments/technologies, namely, T1 $=$ Control (farmer practice), $\mathrm{T} 2=150$ $\mathrm{kg} / \mathrm{ha}$ urea and T3 $=110 \mathrm{~kg} / \mathrm{ha}$ urea and $100 \mathrm{~kg} / \mathrm{ha}$ NPS were evaluated and demonstrated on 4 farmers' fields on plot size of $400 \mathrm{~m}^{2}$ in each study districts. The collected data were analyzed using descriptive statistics (mean and standard deviation) and qualitative narrations. The agronomic result showed that $\mathrm{T} 3$ performed better in average herbage dry matter yield (12.44 t/ha) followed by T2 ( $8.71 \mathrm{t} / \mathrm{ha})$ and T1 which gave lower yield $(5.5 \mathrm{t} / \mathrm{ha})$. The two treatments/technologies (T3 and T2) had a yield advantage of $55.76 \%$ and $36.83 \%$, respectively, over the control across the study districts. The overall technology preference score of all districts showed that T $3(110 \mathrm{~kg} / \mathrm{ha}$ urea and $100 \mathrm{~kg} / \mathrm{ha} \mathrm{NPS})$ and T $2(150 \mathrm{~kg} / \mathrm{ha}$ urea) were the most preferred technologies and ranked as first and second, respectively, by participants because of high biomass, fast growth habit, early maturing for harvesting, plant height, leafiness and species diversity at all districts. Therefore, the combination of Urea and NPS fertilizer at a rate of $110 \mathrm{~kg}$ and $100 \mathrm{~kg} / \mathrm{ha}$, respectively, was recommended to be promoted in large scale in the study areas and other places with similar agro-ecologies.
\end{abstract}

Keywords: Demonstration, Evaluation, Grazing land, Herbage dry matter, Technologies

DOI: $10.7176 / \mathrm{JAAS} / 70-02$

Publication date: January $31^{\text {st }} 2021$

\section{Introduction}

Sub-Saharan livestock production and productivity are very low; one of the major constraints is the poor quality and inadequate quantity of feed available (Kindomihou et al,2014). Given decreasing grazing land and increasing production of cash crops, agro industrial by-products could become important inputs in feed rations for different classes of livestock but it is highly costly and not easily available everywhere. Hence, livestock production can be improved through good management of natural grasslands and introduction of improved fodder species with the supply of fertilizer and water to maintain high productivity (Anneessens, 1989).

Lack of nutrients, inadequate management of pastures, and inappropriate cultural practices are responsible for pasture degradation (Werner 1994). Low nitrogen availability has been identified as a major cause of degradation of tropical pastures (Werner 1994), and the constant removal of forage without proper supply of nutrients extracted by plants emphasizes the problems of grazing land degradation. The application of nitrogen has proved to be effective in maximizing the leaf area and the production of dry matter and nutritional status of grasses (Bonfim-Silva and Monteiro, 2006; Batista and Monteiro, 2008). Habtemichael (2010) and Habteslassie (2009) reported that nitrogen deficiency in the grazing areas could be the leading constraint for limited plant growth and reduced biomass yield. Hence, application of nitrogen seems imperative to enhance plant growth and increase herbage biomass production. This study was, therefore, conducted to evaluate, demonstrate and promote grazing land improvement technology through top dressing with nitrogen and phosphorous fertilizer.

\section{Materials and Methods}

Site and Farmers Selection

The study was conducted in Boneya Boshe, Wayu Tuka, Guto Gida and Diga districts of East Wollega, zone; 
Horro and Guduru districts of Horro Guduru Wollega zone of Oromia Region during 2017/2018 cropping season. To apply the technologies, grazing areas under cut and carry grazing system was purposively selected in each district. Selection of the districts was based on accessibility for field monitoring and visit and potentiality for grazing land, livestock population and compatibility with the AGP II criteria. One potential peasant association (PA) was selected from each district. In each PA, one farmer research extension group (FREG) comprising 16 farmers were established.

In each FREG four hosting farmers were selected with the rest being participant farmers. Development Agents and district experts collaborated in site and farmer selection. The FREG member farmers were selected based on willingness; accessibility for supervision of activities; good history and experience in working in group and willingness to share innovations to other farmers. Besides; the experimenting farmers were selected based on availability of sufficient grazing land to accommodate the trials; vicinity to roads so as to facilitate the chance of being visited by other farmers; good history of handling experiments in the past; genuineness and transparency to explain the technology to others.

\section{Stakeholders' training}

After the establishment of the FREGs a theoretical training was given to farmers, Development agent (DAs) and district experts. The training was given by researchers on management and utilization of grazing land.

\section{Field design and management}

Three treatments $(\mathrm{T} 1=$ Control, $\mathrm{T} 2=150 \mathrm{~kg} / \mathrm{ha}$ urea and T3 $=110 \mathrm{~kg} / \mathrm{ha}$ urea and $100 \mathrm{~kg} / \mathrm{ha}$ NPS $)$ were applied side by side on adjacent plots with a plot size of $20 \mathrm{~m}$ x $20 \mathrm{~m}$ with $3 \mathrm{~m}$ distance between plots at each experimental sites. The amount of nitrogen in T2 and T3 is the same. Then, the difference between T2 and T3 is expected to be due to $\mathrm{P}$. Nitrogen was applied in the form of urea as a split dressing (one-third at seven days of the first rain and two-thirds after about a month of the first rain and $\mathrm{P}$ was applied at seven days of the first rain together with the nitrogen applied at seven days after the first rain.

\section{Participatory evaluation of the technologies}

Experience sharing programs (field days) were arranged to supplement the theoretical training. The technologies were then evaluated based on the farmers' selection criteria for grazing land. At the end of the evaluation process, results of the evaluation were displayed to the evaluators, and discussions were made on the way forward.

\section{Data Collection and Analysis}

Agronomic data like, growth habit (fast/ slow), plot cover, plant height, leafiness and yield data (herbage dry matter yield), total number of farmers participated in training, field visits and field days, farmers' perception on the characteristics of technology, stakeholders participation were collected and analyzed using SPSS statistical package software. Descriptive statistics such as mean, standard deviation (SD), frequencies, and percentages were used to analysis the data.

\section{Results and discussion}

\section{Training of farmers and other stockholders}

Training was given by researchers, who came from Bako agricultural research center on issues such as grazing land improvement techniques, general grass land management and utilization system to farmers, district experts and development agents (DAs) to improve their knowledge and skills on the technologies. Accordingly, a total of 187 participants (153 farmers, 12 experts, 6 supervisors and 22 Das) were trained (Table 1). Of the total trainees, $62.03 \%$ were male and the rest $37.96 \%$ were females.

Table 1. Training participants across five demonstration districts

\begin{tabular}{|c|c|c|c|c|c|c|}
\hline \multicolumn{2}{|c|}{ Farmers } & \multicolumn{2}{c|}{ Experts } & \multicolumn{2}{c|}{ DA's } & \multirow{2}{*}{ Total } \\
\hline Male & Female & Male & Female & Male & Female & 187 \\
\hline 94 & 59 & 8 & 4 & 14 & 8 & 187 \\
\hline
\end{tabular}

\section{Farmers' technology evaluation and selection}

Technical groups (Researchers, Experts and DA's) and farmers jointly evaluated the technologies based on set criteria. Growth habit (fast/slow), early maturing at $50 \%$ blooming stage, biomass (plot cover), plant height, leafiness, logging, weed offensive and species diversity were identified as the most important selection criteria by the participants. A total of 108 farmers composed of men and women participated in the selection process. Participant farmers scored each technology by each trait that was considered important by them and ranking of technologies were done on a scale of 1-5; 1 being the highest score, representing superiority and 5 representing very poor. Biomass yield and growth habit were considered as the most important selection criteria for each grazing land improvement treatments. The total and mean score result showed that T3 (application of $110 \mathrm{~kg} / \mathrm{ha} \mathrm{urea} \mathrm{and}$ 
$100 \mathrm{~kg}$ /ha NPS) and T2 (application of $150 \mathrm{~kg} / \mathrm{ha}$ urea) were the most preferred technologies and ranked as first and second, respectively, by participants at all districts (Table 2).

Table 2: Total and mean score ranks for Grazing land management technologies in the study areas

\begin{tabular}{|c|c|c|c|c|c|c|c|c|c|c|c|c|c|}
\hline \multirow{2}{*}{$\begin{array}{l}\text { Treatments/ } \\
\text { Technologies }\end{array}$} & \multicolumn{3}{|c|}{ Guduru } & \multicolumn{3}{|c|}{ Guto Gida } & \multicolumn{3}{|c|}{ Bonaya Boshe } & \multicolumn{3}{|l|}{ Diga } & \multirow{2}{*}{$\begin{array}{l}\text { Overall } \\
\text { Rank }\end{array}$} \\
\hline & $\begin{array}{l}\text { Total } \\
\text { Score }\end{array}$ & $\begin{array}{l}\text { Mean } \\
\text { Score }\end{array}$ & Rank & $\begin{array}{l}\text { Total } \\
\text { Score }\end{array}$ & $\begin{array}{l}\text { Mean } \\
\text { Score }\end{array}$ & Rank & $\begin{array}{l}\text { Total } \\
\text { Score }\end{array}$ & $\begin{array}{l}\text { Mean } \\
\text { Score }\end{array}$ & Rank & $\begin{array}{l}\text { Total } \\
\text { Score }\end{array}$ & $\begin{array}{l}\text { Mean } \\
\text { Score }\end{array}$ & Rank & \\
\hline Control & 31 & 3.44 & $3^{\text {rd }}$ & 23 & 3.56 & $3^{\text {rd }}$ & 27 & 3.00 & $3^{\text {rd }}$ & 26 & 2.89 & $3^{\text {rd }}$ & $3^{\text {rd }}$ \\
\hline UREA & 36 & 4.00 & $2^{\text {nd }}$ & 35 & 3.89 & $2^{\text {nd }}$ & 36 & 4.00 & $2^{\text {nd }}$ & 36 & 4 & $2^{\text {nd }}$ & $2^{\text {nd }}$ \\
\hline $\mathrm{U}+\mathrm{NPS}$ & 41 & 4.56 & $1^{\text {st }}$ & 43 & 4.78 & $1^{\mathrm{st}}$ & 44 & 4.89 & $1^{\text {st }}$ & 43 & 4.78 & $1^{\text {st }}$ & $1^{\mathrm{st}}$ \\
\hline
\end{tabular}

Scoring of farmer's selection criteria was made against: $1=$ growth habit (fast/ slow), $2=$ Early reach at $50 \%$ blooming stage, $3=$ Biomass (plot cover), $4=$ Plant height, $5=$ Leafiness, $6=$ Logging, $7=$ weed offensive and species diversity

\section{On-farm herbage yield performances}

The following figures show the analysis result on herbage yield performance of the technologies demonstrated across study districts. Accordingly, the highest average herbage dry matter yield (12.44 t/ha) was recorded in T3 $(110 \mathrm{~kg} \mathrm{Urea} / \mathrm{ha}+100 \mathrm{~kg} \mathrm{NPS} / \mathrm{ha})$ and followed by T2 $(150 \mathrm{~kg}$ urea/ha) with $8.71 \mathrm{t} / \mathrm{ha}$ yield and the T1 (control/farmers' practice gave lower yield, $5.5 \mathrm{t} / \mathrm{ha}$ (fig 1 and 2). The two technologies had a yield advantage of $55.76 \%$ and $36.83 \%$, respectively, over the control one across the study districts.

Fig 1.Mean of herbage DM yield $\pm \mathrm{SE}$ (ton $\mathrm{ha}^{-1}$ ) of natural grazing land across locations during 2017.

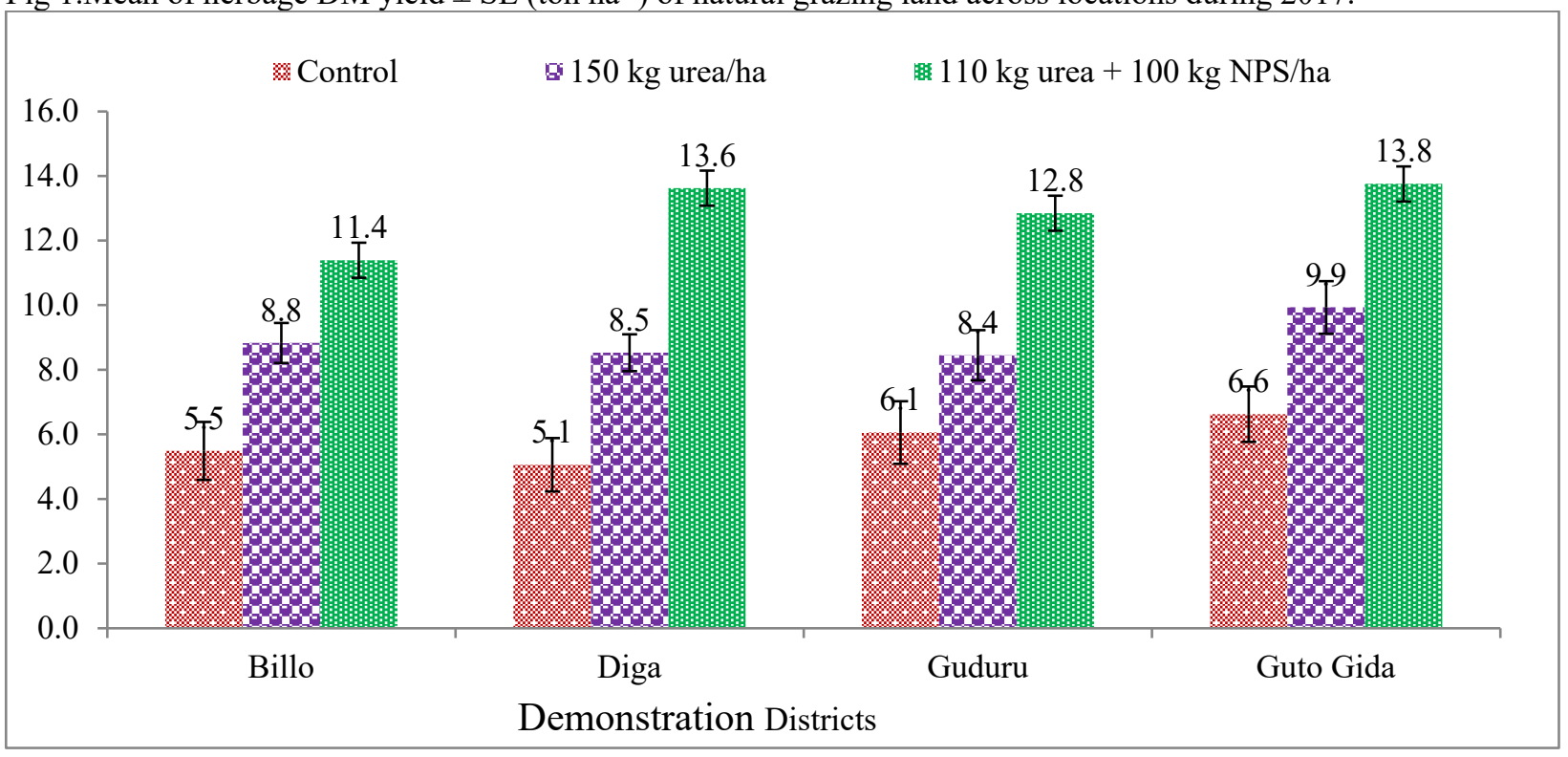

Fig 2.Mean of herbage DM yield $\pm \mathrm{SE}\left(\right.$ ton $\mathrm{ha}^{-1}$ ) of natural grazing land across locations during 2018.

\section{Conclusions and Recommendations}

The demonstration activity was conducted in five AGP II districts using FRG approach in two consecutive years, 2017-2019. Two inorganic fertilizers (Urea and NPS) in sole and in combination and farmers' practices were used for demonstration. The results indicated that application of fertilizer either sole urea or mixed with NPS gave promising herbage DM yield at all demonstration sites. The participant farmers and other stakeholders got better knowledge and skill of using the technologies. Based on the yield and participatory evaluation results, combination of urea and NPS at a rate of $110 \mathrm{~kg}$ and $100 \mathrm{~kg} / \mathrm{ha}$, respectively, were selected as a best technology at all locations followed by T2 (150kg Urea/ha). Therefore, the combination of Urea and NPS fertilizer at a rate of $110 \mathrm{~kg}$ and $100 \mathrm{~kg} / \mathrm{ha}$, respectively, was recommended to be promoted to a large scale in the study areas and other places with similar agro-ecologies.

\section{References}

Anneessens M.,1989. Penissetumclandestinum fertilization trial in Cameron: Qualitative and quantitative aspects. Tropicultural 7(2), pp.54-59.

Batista k. and Monteiro F.A., 2008. Nitrogen and sulphur on morphogenic characteristics of marandu palisade 
grass replacing signal grass under degradation in a low organic matter soil. Brazilian Journal of Animal Science 7, pp 1151-.1160.

Bonfim-Silva E.M. and Monteiro F.A., 2006. Nitrogen and sulphur for productive characteristics of Signal grasses from degradation pasture area. Brazilian Journal of Animal Science 4, pp 1289-1297.

HabtemichaelMezgebe , 2010. Perception of Community on Grazing land Management and Impacton Soil and Vegetation Parameters in the Ethiopian Highlands: The Case of Atsbi-Wenberta in Eastern Tigray. Msc. Thesis presented to Mekelle University, June, 2010.

HabteselassieAsssefa, 2009. Community perceptions and effect of different levels of grazing on vegetation and soil degradation of communal grazing lands in North west Tigray, Northern

Ethiopia. Msc. Thesis presented to Mekelle University, June, 2009.

KindomihouMissiakôValentin, SaidouAliou, Sinsin Brice Augustin, 2014. Response to Fertilizer of Native Grasses (Pennisetumpolystachionand SetariaSphacelata) and Legume (Tephrosiapedicellata) of Savannah in Sudanian Benin.Agriculture, Forestry and Fisheries. Vol. 3, No. 3, 2014, pp. 142-146. doi: 10.11648/j.aff.20140303.11

Werner J.C., 1994. Fertilization of Brachiaria spp.In symposium on pasture management.Pp 209-266. Piracicaba: FEALQ 